Pustovit Yulia,

$\mathrm{PhD}$ (Law Sciences), Kyiv National University of Trade and Economics, 19, Kyoto str., Kyiv, 02156,Ukraine ORCID: 0000-0003-1845-7044

Researcher ID: C-7022-2018

Zapototska Olena, Doctor of Sciences (Law), Kyiv National University of Trade and Economics, 19, Kyoto str., Kyiv, 02156,Ukraine ORCID: 0000-0003-3390-4586

Researcher ID: D-1896-2018

Timashov Viktor, Doctor of Sciences (Law), Kyiv National University of Trade and Economics, 19, Kyoto str., Kyiv, 02156,Ukraine ORCID: 0000-0001-8368-8856

Researcher ID: M-5770-2016

\title{
THE SUBJECTS OF STATE FINANCIAL CONTROL OF UKRAINE IN THE CONTEXT OF EUROPEAN INTEGRATION
}

The article deals with highlighting the essence of key and derived concepts of state financial control; the system of state financial control subjects in Ukraine is studied in the context of European integration. The article substantiates the fact that the clearly defined and legally established organizational structure of state financial control subjects in the country will provide an opportunity to enhance the quality of state financial control which is one of the urgent tasks for the establishment of an effective state control system in Ukraine. Much attention is paid to the fact that in normative-legal acts, namely, in Law of Ukraine «On Fundamental Principles of State Financial Control in Ukraine» the ambiguous concept of «state financial control bodies in Ukraine», main tasks of state financial control bodies, and the functions of state control bodies are consolidated giving an opportunity to the researchers to use various approaches to the concepts mentioned.

Key words: Financial control, state financial control, central executive power bodies, state financial control subjects, the system of state financial control bodies. 
Пустовім Юлія, Запотоцька Олена, Тімашов Віктор. Суб’єкти державного фінансового контролю Украӥни в умовах Евроінтеграції.

Стаття присвячена висвітленню сутності ключових і похідних понять державного фінансового контролю, досліджено систему суб' єктів державного фінансового контролю в Україні в умовах євроінтеграції. У статті обтрунтовано той факт, що чітко визначена $і$ нормативно закріплена організаційна структура суб'єктів державного фінансового контролю в краӥні дадуть змогу підвищити якість державного фінансового контролю, яке є одним із актуальних завдань для побудови дієвої системи державного фінансового контролю в Україні. Особливу увагу у статті приділено тому факту, що в нормативноправових актах, а саме: в Законі України «Про основні засади здійснення державного фінансового контролю в Україні» закріплено не чітке поняття «орган державного фінансового контролю в Україні» та головні завдання органу державного фінансового контролю, функиї органу державного фінансового контролю, що дає змогу науковиям використовувати різні підходи до зазначених вище визначень.

Ключові слова: Фінансовий контроль, державний фінансовий контроль, центральні органи виконавчої влади, суб'єкти держсавного фінансового контролю, система органів держсаного фінансового контролю.

Urgency of the research. Today in Ukraine there is an urgent problem of normative-legal, organizational and technical regulation of organization and activity of state financial control bodies leading jointly to the decrease in efficiency and impartiality of state financial control, the inefficient management of public property and use of budget resources. One of the urgent problems is not established hierarchically-structured legal basis regulating the state financial control. It represents a set of multi-level legal regulations not included in an organized system. There are many normative-legal acts in the state regulating the control function of executive power bodies. However, these norms do not often clarify and simplify relations between controlling bodies of various branches of power, control subjects and objects, but they also introduce the elements of disorganization as well as they do not cover all branches of economic activity leaving them without any control on the side of power.

Problem statement. Finances constitute a fundamental base of civilization. Just like the state, religion, property, market, and money, it is an effective tool of state policy aimed at society life preservation, first of all, at the processes of allocation and reallocation of gross domestic product among various population layers, certain business structures and territories.

The state governs a financial activity through its state bodies and they are vested with special competence for that purpose. All state bodies can be conditionally classified into two groups: one group of bodies, carrying out financial activity, belongs to the bodies of general competence. The other group includes the bodies of special competence established by the state and vested with powers solely for financial activity. 
State financial control has a central place in the implementation of financial and budget policy of the state as well as in the provision of its financial stability. The type of control mentioned is a system of control measures, organization of internal audit, and inspection to ensure optimal management of budget resources and state property. In the leading countries of the world, state financial control is a priority area for the development of financial and budget relations. The conditions of the state financial system depend largely on the effectiveness of the instrument existence.

The amount of budget legislation violations (illegal, including for unauthorized purpose) and inefficient use of budget resources by state power and local selfgovernment bodies, detected by the controlling bodies, is extremely large and increasing every year. Therefore, it is essential to strengthen the institutional basis for preliminary and ongoing control over the management of income and expenditure of budgets at all levels. In particular, the long-lasting focus of the state financial control on elimination of violations and punishment of responsible people has not contributed to improving the efficiency of management and use of financial resources by managers of state budget and local budget funds, their recipients (1).

In the context of budget decentralization, the need for external control over the work of power bodies at different levels is increasing significantly, including during the planning and executing the budgets by them as well as managing and using the financial resources.

Recent research and publication analysis. Many leading researchers have given their attention to the issues of the organization and functioning of the system of state financial control bodies in Ukraine with all its problems and shortcomings. Among the scientific research of national scientists, highlighting the issues of organization and functioning of the system of state financial control bodies, the works of O. Baranovsky, M. Bilukha, F. Butynets, O. Vasylyk, I. Vashchenko, I. Drozd, V. Mamyshev, V. Melnychuk, N. Ruban, L. Savchenko, V. Symonenko, I. Stefaniuk, V. Shevchuk and others deserve attention. However, it should be noted that in their publications, these researchers mostly consider certain practical aspects of the organization and functioning of state financial control.

That is why the aim of the article is to study the existing system of state financial control bodies in Ukraine and substantiate the most reasonable ways of improving the system of state financial control bodies in Ukraine, taking into account the present state of implementation of financial and budget relations at the state and international level.

Presentation of basic material. State financial activity is the regular process of management of public centralized and decentralized funds based on the legal norms and necessary for carrying out the tasks and functions of the state, self-government bodies and other public establishments allowed by the state stipulated by the Constitution of Ukraine.

The Government of Ukraine is still committed to European values and is taking the necessary steps to further provision of Ukraine integration into the European political, economic and legal space. 
The medium-term plan defines the main goals, areas of the Government activity during 2017-2020, the goal of which must be achieved in the system of state financial control of Ukraine at the central, regional and local level, namely: ensuring effective state financial control over the activity of state power bodies and local self-government bodies during management and use of budget resources, including directing state financial control to the increase of the level of effective, legal, goal-oriented, reasonable, efficient use and preservation of financial (material) resources of the state, fixed assets and other assets, achieving growth of budget funds by their managers and recipients, eliminating the detected violations, shortcomings and their further preventing in the course of the activity, increasing the responsibility of heads of public sector bodies for efficiency of activities (1).

The state can function and develop properly only with a clearly organized system of control over the production, distribution and redistribution of the social product and other areas of public life in the state.

In accordance with current legislation, three independent branches of financial control have been established and developed in most countries of the world, containing all their elements, namely:

- The state field where the system of state financial control operates;

- The municipal field where the system of financial control of local selfgovernment operates;

- The field of civil society with an independent system of financial control.

The central place among these financial control systems belongs to the system of state financial control, determined by the role of the state in the market transformation processes. That is why, in our study, special attention will be given to state financial control in Ukraine.

In view of this, strengthening and improving the system of state financial control is essential. The subjects of state financial control are the bodies of state power, which, according to constitutional provisions, is divided into legislative, executive and judicial. The subjects mentioned constitute the controlling bodies of Ukraine, the combination of which is the infrastructure of state financial control of the country.

According to Article 1 of the Law of Ukraine «On Fundamental Principles of State Financial Control in Ukraine» amended, the implementation of state financial control in Ukraine is ensured by a central executive power bodies authorized by the Cabinet of Ministers of Ukraine to implement state policy in the field of state financial control (state financial control bodies) (2).

Article 1 of the Law of Ukraine «On Central Executive Power Bodies» amended, stipulates the definition and system of central executive power bodies of Ukraine, namely: the system of central executive power bodies consists of ministries of Ukraine and other central executive power bodies. The system of central executive power bodies is a component of the system of executive power bodies, the supreme body of which is the Cabinet of Ministers of Ukraine. Ministries provide for the 
development and implementation of state policy in one or more domains, other central executive bodies perform separate functions for the implementation of state policy (3).

Therefore, a central executive power body ensures the exercise of state financial control authorized by the Cabinet of Ministers of Ukraine to implement state policy in the field of state financial control. At present, there are nineteen Ministries in Ukraine providing for the development and implementation of state policy in one or more domains.

In turn, other central executive power bodies are created in the form of services, agencies, and inspections, to perform certain functions for the state policy implementation.

The activities of the central executive power bodies of Ukraine is directed and coordinated by the Cabinet of Ministers of Ukraine through the respective ministries in accordance with the legislation.

There are certain tasks for each central executive power body in Ukraine. The main tasks of central executive power bodies are as follows:

1) Provision of administrative services;

2) State supervision (control);

3) Management of state property objects;

4) Submission of proposals to ensure the development of state policy for ministers' consideration directing and coordinating their activities;

5) Implementation of other tasks provided by the laws of Ukraine (4).

Central executive power bodies can execute one or several tasks mentioned above.

If most of the functions of the central executive power body are functions of providing administrative services to natural persons and legal entities, the central executive power body in Ukraine is formed as a service.

If most of the functions of the central executive power body are functions of managing state-owned objects belonging to the field of its management, the central executive power body is formed as an agency.

If most of the functions of the central executive power body are control and monitoring functions for the compliance of state bodies, local self-government bodies, their officials, legal entities and natural persons with legislative acts, the central executive power body is formed as an inspection.

Today there are twenty four services, fourteen agencies, four inspections, seven central executive power bodies with special status, four collegial bodies and three central executive power bodies belonging to others in Ukraine (the last three organizational types are not mentioned in the Law of Ukraine «On Central Executive Power Bodies»). To sum up, in Ukraine, in general, the system of central executive power bodies consists of seventy six central executive power bodies, the supreme body of which is the Cabinet of Ministers of Ukraine.

Conclusion. Therefore, in our study of state financial control subjects in the context of European integration, we have found out that there is no single system of subjects exercising state financial control in Ukraine. In Ukraine parliamentary control 
is exercised exclusively by the Accounts Chamber, governmental control is exercised by the State Audit Service of Ukraine as well as the Ministry of Finance of Ukraine, and in turn the Ministry of Finance of Ukraine governs other central executive power bodies, performing certain functions for the implementation of state policy in the field of state financial control and other central executive power bodies performing certain functions for the implementation of state policy in the field of state financial control.

Ukraine also requires to address the issues of normative-legal, organizational and technical regulation of organization and activity of state financial control bodies leading jointly to the decrease in efficiency and impartiality of state financial control, the inefficient management of public property and use of budget resources. One of the urgent problems is not established hierarchically-structured legal basis regulating the state financial control. It represents a set of multi-level legal regulations not included in an organized system. There are many normative-legal acts in the state regulating the control function of executive power bodies. However, these norms do not often clarify and simplify relations between controlling bodies of various branches of power, control subjects and objects, but they also introduce the elements of disorganization as well as they do not cover all branches of economic activity leaving them without any control on the side of power. First of all, it appears in inconsistency of normative-legal acts, vagueness of definitions, and lack of specific mechanisms of interaction. It is obvious that current legal documents in the field of state financial control of Ukraine must be harmonized and systematized.

\section{REFERENCES}

1. Verkhovna Rada of Ukraine. Seredniostrokovy plan priorytetnykh diy Uriadu do 2020 roku. (Medium-term plan of priority actions of Government up to 2020). Retrieved from: http://zakon2.rada.gov.ua/laws/show/275-2017-\%D1\%80 (in Ukrainian)

2. Zakon Ukrainy «Pro osnovni zasady zdiysnennia derzhavnoho finansovoho kontrolu v Ukraini» № 2939-XII vid 26.01.1993 (Law of Ukraine «On Fundamental Principles of State Financial Control in Ukraine») Retrieved from: http://zakon2.rada. gov.ua/laws/show/315/96-Bp. (in Ukrainian)

3. Zakon Ukrainy «Pro Tsentralni organy vykonavchoy vlady» № 3166-VI vid 17.03.2011 (Law of Ukraine «On Central Executive Power Bodies»). Retrieved from: https://zakon.rada.gov.ua/laws/show/3166-17 (in Ukrainian)

4. Postanova KMU «Polozhennia pro Ministerstvo finansiv Ukrainy» № 375 vid 20.08.2014 (Regulation on Ministry of Finance of Ukraine). Retrieved from: https://zakon.rada.gov.ua/laws/show/375-2014-\%D0\%BF (in Ukrainian) 